\title{
Design History Exhibitions: The critical interaction of people and practice
}

\author{
Dr Noel Waite \\ University of Otago/Edinburgh Napier University Leverhulme Fellow 2010 \\ Design Studies Dept, University of Otago, PO Box 56, Dunedin, NEW ZEALAND \\ noel@design.otago.ac.nz
}

\begin{abstract}
Exhibition design is a field of practice that embodies what Richard Buchanan has described as the 4 orders of design: objects, symbols, interactions and environments $(2001,2005)$. Unlike many other fields of design practice, exhibition designers are often in a unique position to observe the interactions they and their audience co-create. This is not the narrow kinaesthetic sense in which interaction design is often defined in science centres and museums, but a form of pattern-making inquiry facilitated by a collaboratively researched and designed cognitive map (Lake-Hammond \& Waite).
\end{abstract}

Since the Industrial Revolution, museum and industrial exhibitions have formed a key point of contact between designers + their designs and potential consumers + users. However, as design increasingly addresses sustaining human and environmental relationships, there is a greater need for design exhibitions to explain design processes and their interaction with specific cultures and society. By reframing Design History exhibitions as a series of ongoing interactions between designers, people and particular historical and geographical contexts, the way is open for a more nuanced and critical understanding of design by producers and users alike.

My aim in curating and co-designing Design History exhibitions is to be inclusive: to communicate with experts and non-experts alike in a way that creates rather than determines dialogue. By encouraging reflection on the effects of design in society and in design as a process and practice, I seek to open a productive interaction between designers and the people for whom they design. This poster explores the relationship of Design History research and exhibition design practice by means of reflective practice (Schon), reflecting in an exhibition I am co-curating on New Zealand graphic designer Leo Bensemann for the Christchurch Art Gallery in 2011.

Design History \& Criticism. Exhibition Design. Interaction Design.

\section{REFERENCES}

Buchanan, R. (2001) Design Research and the New Learning. Design Issues, 17(4), 3-23.

Buchanan, R. (2005). Design as Inquiry: The Common, Future and Current Ground of Design. In Redmond, J., Durling, D., \& de Bono A. (eds), Futureground Conference Volume 2: Proceedings. Monash University, Melbourne. CD

Lake-Hammond, A \& Waite, N. (2010) Exhibition Design: Bridging the Knowledge Gap. The Design Journal, 13, 77-98.

Schon, D. (1995) The Reflective Practitioner. Basic Books, Aldershot.
Waite, N. (2001) 'Aventur und Kunst' in New Zealand: The Art of Leo Bensemann. Turnbull Library Record, 34, 87-98.

Waite, N. (2006) The Lay of the Case: Putting New Zealand Communication Design on the Map. The National Grid, 1, 40-47, 65. 